MANOLO FLORENTINO

\title{
De escravos,
}

forros e fujões

no Rio de

Janeiro imperial

MANOLO

FLORENTINO

é professor do

Departamento de História

da Universidade Federal

do Rio de Janeiro. 
।

Fevereiro de 1848 findava quando as duas mulheres chegaram ao derradeiro acordo. Nenhuma se atreveu a colocar as coisas desse modo, mas no frigir dos ovos a escrava Leonor Moçambique poria as mãos na tão sonhada carta de liberdade logo que Vitoriana Rosa do Amor Divino partisse desta para melhor. Até lá a africana continuaria vendendo seus quitutes pelas ruas da Corte, vez por outra lavando, quarando, engomando e passando para fora, de tudo prestando contas à senhora.

Em março o ajuste foi registrado em cartório, ocasião em que Vitoriana fez questão de deixar consignado no livro de escrituras o motivo da manumissão: "a escrava provia o seu sustento e o da casa com o seu jornal" (I ). Vitoriana Rosa do Amor Divino não era a única mulher pobre a ter uma preta por arrimo, nem os registros de alforrias (2) são as únicas fontes a atestá-lo. $\bigcirc$ traço muitas vezes corrosivo de Jean Baptiste Debret capturou situação semelhante quando em termos estritamente econômicos cessavam as diferenças entre senhores e escravos (cf. Figura I) (3). Nada mais natural em uma sociedade em que mesmo os mais pobres almejavam distanciar-se do torpe mundo do trabalho - isto é, sonhavam viver às custas do trabalho alheio. Nada mais comum em se tratando de uma cidade na qual os aluguéis e jornais obtidos com os escravos não raro se aproximavam do que se lograva alcançar alugando casas, com a importante diferença de que o retorno do investido em almas era mais rápido do que o capital aplicado em prédios urbanos (4).

Ilusória era no entanto a inversão da dependência contida na circunstância de Leonor, e pouco demorou para que se soubesse quem realmente mandava. Ano e meio após consignar o registro da liberdade condicional da preta, Vitoriana Rosa do Amor Divino voltou ao notário para revogar

1 Livros de Registros de Notas do Segundo Ofício do Rio de Janeiro, livro geral 79, p. 159 (Arquivo Nacional, RJ).

2 Alforria. s. f. liberdade que o senhor dá ao escravo. Do árabe alhorria.

3 Cf. Rodrigo Naves, "Debret, o Neoclassicismo e a Escravidão", in Rodrigo Naves, A Forma Difícil. Ensaios Sobre Arte Brasileira, São Paulo, Atica, 1997, pp. 91 e sgs.

4 Baseado em análise de inventários post-mortem da cidade do Rio de Janeiro, Roberto Guedes Ferreira, afirma que "aluguéis e/ou jornais de escravos às vezes não distavam tanto dos aluguéis de casas térreas $[. .$.$] e que o retorno do$ capital investido em escravos seria mais rápido do que o investido em prédios urbanos" (Na Pia Batismal: Família e Compadrio entre Escravos na Freguesia de São José do Rio de Janeiro PrimeiraMetade do Século XIXI, dissertação de mestrado, Niterói, Departamento de História da Universidade Federal Fluminense, 2000 , pp. 131-81 
5 Livros de Registros de Notas do Terceiro Ofício do Rio de Janei10, livro geral 9, p. 67v (Arqui vo Nacional, R\|l.

6 Livros de Registros de Notas do Segundo Ofício do Rio de Ja neiro, livro geral 69, p. 100v Arquivo Nacional, RN).

7 A analogia óbvia é com a reflexão que Marshall Sahlins desenvolve sobre o papel da guerra em sociedades tribais lcf. Las Sociedades Tribales, Barcelona, Editorial Labor, 1984, pp. $11-28$

$8 \bigcirc$ Code Noir francês é invenção de Colbert, promulgada por Luis XIV em 1685. Os Códigos Negros hispano-americanos, por sua vez, são expres sões do despotismo ilustrado spanhol e surgiram na segunda metade do séculoXVIII como meio de tornar mais rentáveis as colônias insulares do Caribe. Sobre eles, cf. Lovis SalaMolins, Le Code Noir ou le Calvaire de Canaan, Paris, PUF, 1988: e Manuel LucenaSalmoral, Los Códigos Negros de la América Española, Paris/ Madrid, Unesco/Universidad de Alcalá, 1996 a alforria. Foi econômica nos motivos: "por ingratidão [a escrava] deixou de cumprir o [seu] dever; [é] indigna do benefício" (5).

Até o momento encontrei exatas quatro revogações de alforrias entre mais de 17.500 cartas de liberdade coletadas entre 1840 e 1871. A rarefação de anulações pode ser tomada como signo do desuso a que semelhante estatuto foi circunscrito no decorrer da época moderna, ou ainda e primordialmente como expressão da eficiência com que senhores e escravos pactuavam a obtenção da liberdade. De todo modo, a existência de uma única revogação bastaria para indicar o quanto era legitimamente instável a liberdade ensejada pela lei escravocrata.

Em princípio - e na letra da lei -, os que alforriavam julgavam poder reescravizar, e quem obtinha a liberdade acreditava poder regressar ao cativeiro. O que não impediu ao marquês de Jacarepaguá exigir, em janeiro de 1840 , que se consignasse no próprio livro em que ele condicionava a alforria de José Maria de Nação à prestação de serviços: “a liberdade cairá se não se conduzir bem ou faltar com o respeito" (6). Entre- tanto, a mesma sociedade que tornava movediça a liberdade igualmente fazia da volta ao cativeiro, mais do que uma realidade, uma circunstância subjacente e remota. Então: é possível que a escassez de anulações de liberdade remeta à força de determinados padrões culturais que, precisamente, tornavam pouco freqüente o retorno à escravidão. Tratava-se de uma cultura da manumissão cuja sabedoria era esta: tornar virtual o que tecnicamente estava carregado de legitimidade (7). Não surpreenderia descobrir nessa cultura elementos que, ausentes em outras regiões das Américas, impediram vicejar no Brasil um Código Negro regulador das relações entre senhores e escravos (8).

Óbvio, para aqueles que partilhavam da cultura da manumissão - e é bom lembrar que nem todos os atores sociais dela compartilham, incluídos aí não apenas senhores mas também muitos escravos -, o cativeiro era em princípio uma condição temporária. E a liberdade também. Pois tudo se passava como se, embora a escravidão pudesse ter fim, fossem perenes os moti-

FIGURA 1

J-B. Debret,

Família Pobre

em sua Casa,

in Viagem

Pitoresca,

1834-39

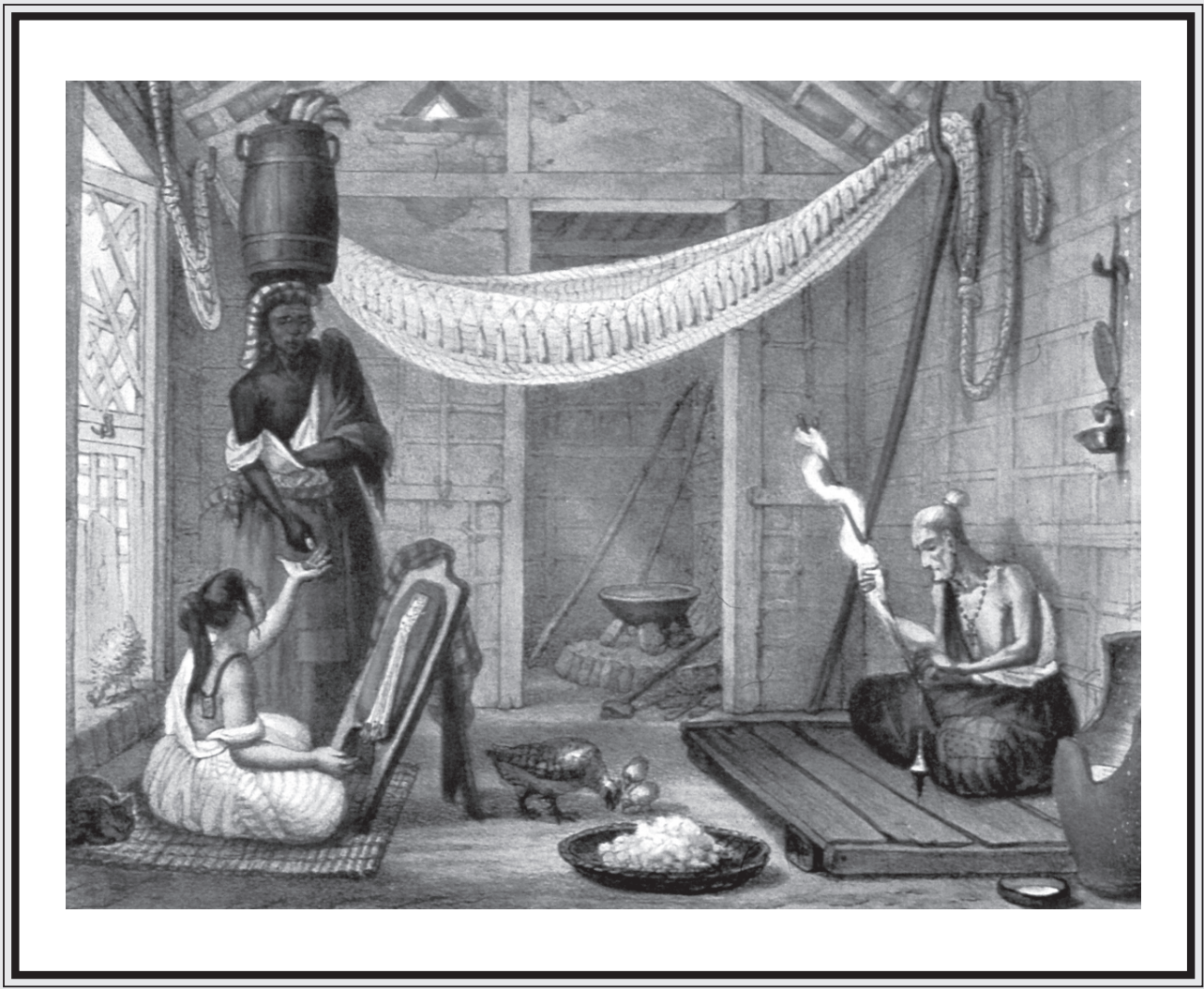


vos que lhe teriam dado origem, razão pela qual era necessariamente provisória a própria liberdade conquistada. A inferioridade fundadora do escravo tornava provisional mesmo a eventual manumissão, idéia presente tanto no pensamento clássico quanto no cristianismo.

Platão - lembra David Brion Davis acreditava que a perpétua inferioridade do escravo se expressava através da natureza hereditária do status servil. E que até "o forro estava obrigado a servir a seu primeiro senhor, não havendo garantias que evitassem que seu ser fosse novamente reduzido à escravidão" (9). Para a cristandade a escravidão relacionava-se ao pecado original, embora não sem ambigüidades. No âmbito colonial ibérico, muitos letrados (sobretudo jesuítas) foram a esse respeito precisos: ao fazer fluir nos homens os apetites inerentes à sua condição, a queda do Paraíso gerou a guerra da qual derivara o cativeiro legítimo - isto é, a escravização do prisioneiro a quem se poupava da morte (servatus) (10).

Os fundamentos da sempiterna inferioridade do negro eram ressaltados pelos exegetas de Santo Agostinho, mas também pelas vulgatas da Bíblia, sobretudo a tradução latina feita em parte por São Jerônimo no século IV, declarada de uso comum pelo Concílio de Trento. Logo os etíopes - isto é, os "caras queimadas" - passaram a ser associados aos descendentes de Cã, o filho de Noé que fora amaldiçoado pelo pai por haver zombado de sua nudez, razão pela qual deveriam servir aos descendentes de Sem e Jafet (os asiáticos e os europeus, respectivamente). Não eram poucos, além disso, os que acreditavam descenderem os negros de Caim, o qual havia sido amaldiçoado pelo próprio Deus (11). Marcados assim pelo vício (penitus in vitio demersi sunt), os negros encontravam na escravização a saída natural para ao menos minorálo (12). A inferioridade tinha cor (preta) e estatuto jurídico (escravo), não demorando muito para estas noções tornarem-se plenamente intercambiáveis (13).

A viragem ideológica representada pelo Systema naturae (1735), de Carl
Linneu, inscreveu em definitivo o homem no reino animal, mas de modo igualmente racializador. Seus seis tipos de sapiens multicores instauraram uma hierarquia natural na qual o africano (Afer niger), de pele negra e acetinada, com cabelos crespos e negros, de nariz achatado e lábios túmidos, o ar fleugmático e relaxado, a natureza indolente e negligente, e o hábito de ser governado pelo capricho de seus senhores jamais seriam compensados pela engenhosidade e astúcia das quais também era provido. Estava o negro, pois, condenado não apenas a diferir-se mas também a ver-se inferiorizado diante do europeu (Europaeus albus), branco, de cabelo louro ou castanho, olhos azuis e aparência delicada, sangüíneo e musculoso, perspicaz e inventivo, coberto por vestes adequadas e governado por leis (14).

\section{II}

Os termos em que em abril de 1849 foi escrita uma carta de liberdade podem ajudar a avançar na discussão. Nela, Sebastião Pires Ferreira libertava Isabel Benguela mediante uma única condição:

“que [Isabel] não viva nesta Corte nem na Província do Rio de Janeiro, podendo em qualquer outra parte do Brasil estabelecer sua residência e usar e gozar de si como the aprouver; no caso porém de que seja encontrada nesta Corte ou [em] qualquer [outro] lugar da província, ficará esta liberdade de nenhum efeito, e a mesma [escrava] voltará à minha posse e domínio [...]"(15).

O acordo desvela como poucas fontes os elementos em jogo no ato de alforriar, permitindo uma primeira apreciação ao conteúdo da liberdade conservadora em jogo. Obtido por mérito, acordo ou compra, um documento legal consignava a transferência da propriedade escrava do senhor para o próprio cativo que, assim, se resgatava. O mesmo no entanto não ocorria com o domínio senhorial, que a
9 David Brion Davis, OProblema da Escravidão na Cultura Oc dental, Rio de Janeiro, Civilizo ção Brasileira, 2001, p. 85

10 Cf. José Murilo Carvalho, "Es cravidão e Razão Nacional", in Pontos e Bordados, Belo Horizonte, Editora da UFMG 1999, p. 36

$11 \mathrm{Cf}$. Charles Ralph Boxer, O Im périoMarítimo Português, 1415 1825 São Paulo, Companhia das Letras, 2002, p. 276

12 JoséMurilo de Carvalho, op. cit p. 43. Para detalhes, cf. Ronaldo Vainfas, Ideologia Escravidão. Os Letrados e a Sociedad Escravista no Brasil Colonial Petrópolis, Vozes, 1986, segunda parte. Vainfas lembra, com razão, que a maldição de Cam iá surgia como justificativa do cativeiro negro em leão o Africano (1550) eem Ambrósio Fer nandes Brandão (1618). Ressalto que o mesmo já se dava durante a etapa "africana" $\mathrm{da}$ expansão portuguesa, de modo explícito em Gomes Eanes da Zurara /Crônica de Guiné, Ba celos, Livraria Civilização 1973, p. 85), escrita em meados do séculoXV e implícito en Duarte Pacheco Pereira (Esmeraldo de Situ Orbis, Lisboa Academia Portuguesa de Histó ria, 1988, p. 221, este do primórdios do século XVI. É pos sível que o grande ícone do penamento cristão escravista do tecentos seja Manoel Ribeiro Ro cha, para quem o escravo era um homem com pleno direito a liberdade. Ribeiro Rocha, por vezes ridicularizado como mero sofista, incorpora em seu mode o justificador al a ilegitimidade da propriedade escrava; b) un tempo determinado para o fim do cativeiro; c) a natureza pe dagógica (não apenas cristã) do cativeiro, levada ao extremo Esse autor precisa ser levado mais a sério pois como secular expressava, como não se encon tra em Vieira, Benci ou Azeredo Coutinho, uma mentalidade mais próxima da do homem le go comum. Participa de seu mo delo de cultura da manumissão grande parte das cartas de alforria que tenho coletado para - Rio de Janeiro entre 1840 e 1871, as quais enfatizam a natureza pedagógica do cattveiro e a necessidade de se le gar dinheiro para o forrado começar a nova vida além minorarem a inferioridade do es cravo, estabelecerem um tempo para a duracão do cativeiro afirmarem enfaticamente ser redenção possível - cf. Manoe Ribeiro Rocha, Etíope Resgatado, Empenhado, Sustentado Corrigido, Instruído e Libertado (Discurso sobre a Libertação do Escravos no Brasilde 17581, ed tado por Paulo Suess, Petrópolis Vozes, 1992 

Coração do Império, Lisboa Secretariado Coordenador do Programas de Educação Multicultural - Ministério da Educação, 1999, passim.

14 Cf. Léon Poliakov, O Mito Aria no, São Paulo, Perspectiva 1074 p. 137. Em Carlos Au gusto Taunay Manual do Agricultor Brasileiro, organização de Rafale de Bivar Marquese São Paulo, Companhia das Letras, 2001, pp. 52-31, cujo livro fo ançado no Rio de Janeiro em 1839, pode-se ler: "A inferioridade física e intelectual da raça negra, classificada por todos os tisiologistas como a última da raças humanas, a reduz naturamente, uma vez que tenha contato e relações com outras roças. E especialmente a branca ao lugar ínfimo, e ofícios ele mentares da sociedade. Debalde procuram-se exemplos de negros cuja inteligência e produções admiram. O geral deles não nos parece suscetível senão do grau de desenvolvimento mental a que chegaram os brancos na idade de quinze dezesseis anos. A curiosidade, a imprevisão, as efervescência motivadas por paixões, a impaciência de todo o jugo e inabidade para se regrarem a si mesmos; a vaidade, o furor de se divertir, o ódio ao trabalho, que assinalam geralmente a adoles cência dos europeus, marcam todos os períodos da vida dos pretos, que se podem chama homens-crianças e que carecem viver sob uma perpétua tutela: pois indispensável conservá-los, uma vez que o mal da sua introdução existe, em um estado de escravidão, ou próximo à escrovidão; porém, esta funesta ob gação dá os seus péssimos fru tos, e o primeiro golpe de vista nos costumes, moralidade educação desengana o obse vador e o convence de que a escravidão não é um mal para eles sim para os seus senhoes". São aqui evidentes os ecos de Linneu e da vertente poligenista da llustração, cujo icone é Voltaire.

15 Livros de Registros de Notas do Segundo Ofício do Rio de Janeiro, livro geral 80 , p. $363 v$ (Arquivo Nacional, RJ).

16 Cf. Hebe Maria Mattos, Escravidão e Cidadania no Brasi Monárquico, Rio de Janeiro, Jorge Zahar, 2000, pp. 20-1.

17 Hermann Burmeister, Viagem ao Brasil, Belo Horizonte/São Pau0, Itatiaia/Edusp, 1980, p. 71

18 Apud Jean Marcel Carvalho França, Visões do Rio de Jane ro Colonial (1537-1800), Rio de Janeiro, Edueri/José Olympio, 1999, p. 250.

191 dem, ibidem, p. 251

20 ldem, ibidem carta de manumissão tornava apenas virtual - isto é, passível de a qualquer momento volver-se real devido à existência do estatuto jurídico da reescravização. Eis o fundamento para que muitas alforrias se transformassem, na prática, em mecanismos de contínua produção de patronagem.

A perenidade do domínio senhorial sugere mais uma vez que, no universo da cultura da manumissão, o africano escravizado ou liberto estava marcado por uma inferioridade inata que nem a liberdade podia esconjurar. Prova-o, além da possibilidade de retorno ao cativeiro, a instauração pelo Estado imperial de uma evidente diferenciação entre os forros e seus descendentes no tocante à possibilidade de eventualmente interferir na reprodução do status quo. A Constituição de 1824 distinguia os cidadãos no campo político por meio de suas posses, criando o "cidadão passivo" (sem renda para poder votar), o "cidadão ativo votante" (com renda para votar os membros do colégio de eleitores), e o "cidadão ativo eleitor e elegível", que votava e podia ser eleito. A esse nível chegavam apenas os nascidos livres, o que excluía os libertos, restritos desse modo apenas às duas primeiras categorias (se não fossem africanos, estrangeiros por definição) (16). Provao igualmente um traço recorrente nos escritos dos europeus que visitaram o Brasil, como o zoólogo e naturalista de Strallsund (Alemanha), Hermann Burmeister, que aqui viveu entre setembro de 1850 e princípios de 1852. Logo ao desembarcar no porto do Rio de Janeiro Burmeister observou:

"os homens de cor mais abastados e livres vivem como o homem branco, procurando destacar-se ainda mais do que este pela elegância e apuro do traje [...] Todos se esforçam em imitar, o quanto possível, a moda européia, e nesta camada da população não se vê, igualmente, nenhum traje típico do país. Os objetos mais ambicionados por eles são as jóias de valor, ouro e diamantes, e tudo que possuem neste gênero carregam no corpo, mesmo quando em casa, salientando-se nisto especialmente as mulheres"' (17).

Antes dele oinglês James George Semple Lisle morou no Rio de Janeiro entre novembro de 1797 e fevereiro de 1798, sob o governo do conde de Rezende. Foi o tempo suficiente para perceber o quanto era expressiva a quantidade de escravos que compravam a liberdade com o pecúlio morigeradamente acumulado ("muitos deles, depois de alguns anos de trabalho, conseguem comprar a sua liberdade") (18). Observador atento, igualmente chamou-lhe a atenção o fato de as milícias da cidade serem compostas por três regimentos, um de soldados brancos, outro de negros e outro mais de mulatos. Os soldados mulatos possuíam "ótima aparência" e eram proprietários:

"Digno de nota é o fato de a milícia de mulatos ser composta exclusivamente por homens de posse, homens que podem arcar com os custos do seu fardamento, o qual é azul-claro, ornado com faixas vermelhas e passamanes prateados. No todo o seu aspecto é bastante agradável” (19).

Não demorou para que Lisle estendesse ao regimento de negros a boa impressão obtida junto à soldadesca mulata. Refletindo sobre a origem de semelhante configuração, concluiu:

"A razão pela qual os regimentos de cor são mais alinhados do que o regimento branco é a seguinte: enquanto este é formado por homens pobres e ricos, aqueles são compostos somente por indivíduos que compraram a sua liberdade e que, graças a uma superior capacidade de trabalho, progrediram mais rapidamente do que os outros" (20).

Trabalho, mercado e liberdade. Quando James George Semple Lisle visitou o Rio de Janeiro os preços dos cativos ainda não haviam explodido, como na época de Burmeister. Eis por que muitos conseguiam comprar a liberdade, para logo transformar a qualidade e trato da vestimenta 
em forte signo de distância em relação a um cativeiro já abandonado por meio de trabalho duro e metódico. Não é necessário ser historiador para capturar na tentativa de emprestar a si, por meio do cuidado na aparência, um certo ar de dignidade, um padrão afeito particularmente àqueles que, de algum modo, assumem a inferioridade imposta pelo entorno (21).

\section{III}

Talvez nunca consigamos saber os motivos que levaram Sebastião Pires Ferreira a emprestar à manumissão de Isabel Benguela o evidente tom de desterro isto é, a converter em pena a liberdade em princípio almejada pela escrava e por outros cativos. Contudo, os termos da carta de alforria de Isabel apontam para outros conteúdos da noção de liberdade conservadora que, imaginava-se, poderia ser desfrutada por um ex-escravo. No dia-a-dia tal noção se relacionava à possibilidade de movimentar-se espacialmente, de usar e gozar de seu corpo e dos frutos de seu trabalho, preservando de um modo ou de outro o domínio senhorial. Assim definida, a liberdade se confundia com a possibilidade de, em graus diversos, dispor de si.

Sem nenhuma garantia de êxito, a grande maioria buscava dispor de si na lida impetuosa ou manemolente, associando a "liberdade" a pequenas conquistas tendentes a alargar sua autonomia na escravidão. É claro, alcançar essas pequenas conquistas demandava tempo, o tempo de aculturarse, de vivenciar na carne e na alma a pedagogia que aos poucos transformava o cativo (isto é, o prisioneiro) em escravo. Aos que não lograssem realizar semelhante travessia restava o cativeiro inconforme ou a fuga sem quartel que, com sorte, podia redundar no viver em quilombos, em regressar à África ou até mesmo em reiterar o périplo pelo Novo Mundo, ainda que na condição de livre (22).

A incompletude dessa travessia é um dos aspectos insinuados pela Tabela 1 , que busca dar conta dos perfis etário-sexuais da população escrava da Corte, dos fugitivos que apareciam nos anúncios de fugas do Jornal do Commercio, e dos africanos que desembarcavam no porto do Rio de Janeiro, tudo isso em uma época em que o tráfico atlântico alcançou seu auge. Se, por um lado, fica claro o impacto do tráfico sobre a população cativa urbana (quase $80 \%$ de africanidade e amplo predomínio de homens adultos), por outro se indica igualmente o peso dos recém-chegados entre os fujões, cujos contingentes encontravam-se inflados sobretudo por boçais do sexo masculino entre 12 e 18 anos de idade.

Esses dados indicam poder ser correta a idéia de que nas Américas a frequiência de fugas e de formação de quilombos mantenha uma relação diretamente proporcional aos níveis de africanidade da população escrava (23). Contudo, é perfeitamente plausível que o fundamento de semelhante correlação radique menos em uma etérea resistência escrava ao cativeiro do que no impacto inicial do desarraigo, da solidão e da subtração da linguagem que na África servia à estruturação do mundo. Nessa espécie de estado de seasoning cultural talvez estivessem fujões como o angolano Gongi, ferido no pé direito e que "ainda carrega o nome de sua terra"; João Cassange,12 anos, "bastante esperto porém buçal por ter 5 ou 6 meses deste país"; Rita Cabinda, "que não sabe dizer o nome de sua senhora por ter sido comprada a pouco"; Antônio Moçambique, de 16 anos, que "não sabe dizer o nome de seu senhor"; ou ainda Santos e Vasco, os quais “apenas principiam no português" (24).

Aos que o tempo permitia passarem da condição de simples cativos à de escravos cabia legitimamente almejar maior autonomia no cativeiro, ou mesmo a liberdade conservadora implícita a uma carta de alforria. Creio que no espaço urbano o limite da autonomia na escravidão pode ser exemplificado por meio dos inúmeros escravos ao ganho que, com a complacência senhorial, prestavam conta dos jornais a espaços longos (uma semana, quinze dias ou um mês) e "moravam sobre si" - isto é,
21 Com sua peculiar acidez, e a liberdade própria do ofício de jornalista, há muito Mencken observou: "O escravo está sempre cônscio da sua escrovidão, e faz constantes e de sesperadas tentativas de mitigá-la ou livrar-se dela de uma vez. As vezes, busca este alívio em atividades externas que prometem dar-the a sensação de dignidade e importância que o seu trabalho diário he nega; outras vezes, tenta emprestar uma falsa aparência de dignidade a este próprio trabalho" Icf. Henry Louis Mencken, O Livro dos Insultos de H L Mencken, selecão tradução e prefácio de Ruy Castro, São Paulo, Companhia das Letras, 1988, p. 1381.

22 Cf o caso de Muhammad Baquaqua, in Paul Lovejoy; Robin Law (eds.), The Biography of Mahommah Gardo Baquaqua New Jersey, Markus Wiene Publishers, 200

23 Cf. Richard Price (comp.), So ciedades Cimarronas, México DF, Siglo XXI, 1981, p. 33

$24 \mathrm{Cf}$. Jornal do Commercio de 28 de janeiro de 1850,13 de abril de 1830, 29 de ja neiro de 1840 e 15 de abri de 1830 . 
TABELA 1

Distribuição (\%), por idade, sexo e naturalidade da população escrava (1825-35), dos escravos fugidos (1830-1840) e dos boçais (1822-33) da cidade do Rio de Janeiro

Escravos em inventários (1825-35)

\begin{tabular}{lrrrr}
\hline & \multicolumn{2}{c}{ Africanos } & \multicolumn{2}{c}{ Crioulos } \\
& M & F & M & F \\
0-14 anos & 4,3 & 2,6 & 7,1 & 6,1 \\
15-40 anos & 39,4 & 19,3 & 3,2 & 4,4 \\
+ +40 anos & 9,1 & 3,4 & 0,8 & 0,3
\end{tabular}

Escravos fugidos (1830-40)

\begin{tabular}{|c|c|c|c|c|}
\hline & \multicolumn{2}{|c|}{ Africanos } & \multicolumn{2}{|c|}{ Crioulos } \\
\hline & M & $F$ & M & $\mathrm{F}$ \\
\hline $0-14$ anos & 18,7 & 5,5 & 2,3 & 0 \\
\hline $15-40$ anos & 50,3 & 10,9 & 6,8 & 1,4 \\
\hline+40 anos & 2,7 & 0 & 1,4 & 0 \\
\hline \multicolumn{5}{|c|}{ Boçais (1822-33) } \\
\hline & \multicolumn{2}{|c|}{ Africanos } & \multicolumn{2}{|c|}{ - } \\
\hline & M & $F$ & - & - \\
\hline $0-14$ anos & 14,5 & 5,9 & & - \\
\hline $15-40$ anos & 61,2 & 17,8 & & - \\
\hline+40 anos & 0,3 & 0,3 & & - \\
\hline
\end{tabular}

25 Cf. Deneílson Sousa Brito, Mo radias Escravas no Rio de Janei ro no Século XIX, Rio de Janeiro, Departamento de História da UFRJ, 2002, pp. 26-30. De acordo com Karasch," [... muitos negros de ganho, cujos donos confiavam neles, tinham permissão para alugar suas pró prias casas e viver separados dos donos, desde que continuassem a pagar a porcentagem exigida de sua féria diária. Outros podiam viver à parte, de de que cumprissem as tarefa diárias na casa do seu senhor" Mary C. Karasch, A Vida dos Escravos no Rio de Janeiro 1808-1850, São Paulo, Companhia das Letras 2000, p. 186).

26 Cf. por exemplo Jupirac Affonso Rego Rossato, Sob os Olhos da Lei: o Escravo Urbano na Legislação Municipal na Cidade do Rio de Janeiro (1830-1838), Niterói, Departamento de História da Universidade Federal Fluminense, 2002, p. 118.

Fonte: Inventários Post-Mortem, Arquivo Nacional (1825-35), Jornal do Commercio (1830 e 1840 ) e códice 425 do Arquivo Nacional (1822-33).

alugavam ou mesmo eram proprietários de habitações separadas das casas e prédios urbanos nos quais viviam os seus senhores. É possível que tais arranjos envolvessem principalmente senhores pobres, para os quais a ausência dos escravos podia significar redução de custos de manutenção. Do ponto de vista dos escravos, as vantagens da moradia autônoma eram evidentes: privacidade (sobretudo no que tange aos contatos entre escravos e livres pobres), melhores condições de vida, liberdade de movimento, disporem melhor de seu tempotanto em termos de lazer quanto no que se refere à racionalização do trabalho -, dentre outras (25).
De fato, muitos escravos da cidade do Rio de Janeiro logravam extrair de seus senhores a possibilidade de viver em habitações próprias, sendo caso clássico o do escravo Henrique, citado por vários estudos. Tratava-se de um escravo de ganho que, além de ser proprietário de um "zungu” (no caso, um cortiço) na Rua do Lavradio, era ele próprio dono de uma escrava (26). Sobre cativos como Henrique um projeto a ser aditado às posturas municipais de $11 \mathrm{de}$ setembro de 1838 especificava:

"Fica proibido aos senhores de escravos consentirem que eles morem sobre si, a pretexto de quitandarem ou por qualquer ou- 
tro: os transgressores serão punidos com 5 a 15 dias de prisão e multa de 10 a 30.000 réis e os escravos serão castigados com 100 açoites e trarão, por um ano, ferro ao pescoço, penas estas que serão dobradas havendo reincidência" (27).

Quase um quarto de século depois, entretanto, continuava a ser comum escravos viverem em moradias por sua própria conta, desfrutando de ampla autonomia espacial. É o que enviesadamente mostra o ofício da polícia enviado à Câmara Municipal da Corte em 19 de março de 1860:

"Ilmo. Snrs, existe nessa cidade um grande número de casas alugadas diretamente a escravos, ou a pessoas livres, que parcialmente a sublocam a escravos. Os males resultantes de uma tal prática são notórios, ninguém ignorando que essas casas, além de serem valhacoutos de escravos fugidos e malfeitores, e mesmo ratoneiros livres, tornam-se verdadeiras espeluncas, onde predominavam o vício baixo de mil formas diferentes. Urgente seria, pois, reprimir severamente tal abuso, proibindo-se alugar, ou sublocar qualquer casa, ou parte dela a escravos, ainda mesmo munidos de autorização do seu senhor" (28).

Exemplos como esses mostram terem razão os historiadores que, longe de absolutizar a resistência escrava, nela descobrem sentidos múltiplos, alguns apenas reivindicativos, outros claramente absorvíveis (29). Tal pode ter sido o caso protagonizado por Roberto, cujas intenções não eram tão inassimiláveis assim. Afinal, desde que sumira, quatro dias antes do anúncio de sua fuga ser estampado no Jornal do Commercio, Roberto não fazia muita questão de se esconder, tendo sido visto a perambular por bairros tão díspares como Laranjeiras, São Cristóvão e Catete (30).

Mas o dispor de si podia se alargar até traduzir-se na transferência jurídica da propriedade do senhor para o próprio escravo. Ato revogável até 1871 , implicava que o infeliz deixasse de ser escravo, embora no plano mais geral das práticas e representa- ções sociais não necessariamente apagasse os rastros da dependência pretérita. Era essa a liberdade buscada mediante cartas de alforria. Tratava-se de um anseio em princípio geral, mas cuja obtenção era mais premente para certos espíritos do que para outros. O regresso à África, por exemplo, pode ter sido a obsessão que manteve viva Felícia Maria até que fosse autorizada a embarcar rumo a Angola, em meados de 1829. Pode-se imaginá-la, entre alegre e ansiosa, a abordar o navio no qual teria início a travessia em tudo oposta ao passado, carregando colada ao corpo a carta de liberdade assinada por Silvestre Manoel, o mais valioso de seus ralos bens (31).

Outras circunstâncias da vida tornavam urgente a obtenção de uma carta de liberdade - como quando o escravo formava família ou estabelecia descendência, por exemplo. Talvez por não havê-la conseguido é que a preta Rosa, uma fornida quiçamã de 40 anos, fugiu da casa de número 103 da Rua Larga de São Joaquim, levando consigo tão-somente uma caixa de roupas e, no ventre, uma criança de cinco meses (32). Caso oposto ao de Rosa Cabinda, alforriada em 1841, juntamente com a filha, Angélica. Francisco Ferreira de Assis obteve por elas 800 mil réis, das mãos do preto mina Guilherme João - presumivelmente o pai de Angélica -, que de imediato recebeu Rosa em casamento (33).

\section{IV}

Diversos são os meios de se obter a liberdade conservadora característica da manumissão. Diversos e sobretudo qualitativamente distintos, aspecto algo negligenciado pela historiografia brasileira. Assim, ao teorizar sobre os móveis das flutuações das alforrias brasileiras, Manuela Carneiro daCunha escreveu: "Já foi assinalada a maior incidência de alforrias emépocas de recessão econômica, quando o mercado não absorvia escravos ou estes se tornavam um peso. Alforriá-los mediante pecúnia era uma maneira de reaver um capital” (34).

\footnotetext{
27 Cf. Códice 6-1-28, Arquivo Geral da Cidade do Rio de Janeiro, reproduzido por Rossato (op. cit., anexo 5).

28 Cf. Códice Escravos 3,3,37 Arquivo Geral da Cidade do Rio de Janeiro, citado por Brito lop. cit., p. 29)

29 Cf. por exemplo João José Reis: Eduardo Silva, Negociação Conflito, São Paulo, Compo nhia das Letras, 1989

30 Jornal do Commercio de 13 de março de 1850

31 Arquivo Nacional (RI), códice 424 , vol. 3 , p. 51

32 Jornal do Commercio de 23 de outubro de 1850

33 Livros de Registros de Notas do Segundo Ofício do Rio de Janeiro, livro geral 70 , p. 70 (Arquivo Nacional, RJ).

34 Manuela Carneiro da Cunha Negros, Estrangeiros los Escra vos Libertos e sua Volta à Africal, São Paulo, Brasiliense ca), São Paulo,
1988, p. 49
} 
35 David Brion Davis, Slavery in the Colonial Chesapeake Williamsburg, The Colonia Williamsburg Foundation, 1997, pp. 21-2

36 Thomas W. Merrick; Dougla H. Graham, População e De senvolvimento Econômico no Brasil, Rio de Janeiro, Zahar, 1981 , pp. 76 e sgs.

$37 \mathrm{Cf}$. por exemplo Sidney Chalhoub, Visões da Liberdade, São Paulo, Companhia da Letras, 1990; Eduardo França Paiva, Escravos e Libertos nas Minas Gerais do Século XVIII São Paulo, Annablume, 1995

38 Carlo G. Monti, O Processo de Alforria: Mariana (1750-1779), dissertação de mestrado, São Paulo, Depto. de História da USP, 2001, pp. 23-30.
Há aqui, quando menos, traços de um modelo. Em primeiro lugar, implicitamente se assume a natureza estrutural das manumissões no Brasil - isto é, a sua reiteração temporal, embora flutuante, ao longo de toda a época da escravidão. Não se trata de aspecto de menor importância: na Virgínia de 1691, por exemplo, chegou-se a proibir toda manumissão privada, a menos que o senhor deportasse o forro para fora da colônia; mulher branca que ali parisse filho mulato era pesadamente multada, ou serva virava por cinco anos (os filhos, por trinta) - uma situação inimaginável em qualquer época de nossa história (35). De fato, os estudiosos concordam em que a sociedade escravista brasileira alforriava como nunca se viu em outras partes das Américas (36).

O trecho acima indica também que, embora reiterativas no tempo, as freqüências de manumissões obedeceriam a tendências inversamente proporcionais às sucessivas fases da economia escravista: maior incidência em fases $\mathrm{B}$ (de recessão), menor em fases A (de expansão econômica). Logicamente falando, não é difícil compreender as alegações para a diminuição das alforrias em fases A - o aumento da demanda por braços não apenas implicaria incorporar mais mão-de-obra, mas também limitar a sua perda mediante libertações. A maior freqüência de manumissões nas fases B, por seu turno, encontraria justificativa em dois argumentos: evitar custos de manutenção (via alforrias gratuitas ou modelos diferenciais de coartação) e/ou reaver em parte ou in totum o preço pago por cativos agora não tão necessários - óbvio, através da compra da alforria pelo escravo.

Por fim, implícita à citação destacada encontra-se a idéia de que a obtenção de uma carta de alforria corresponderia a uma concessão senhorial. No fundamental, dependeria da vontade dos proprietários tanto o travamento relativo das manumissões em fases A quanto o seu incremento em fases B. É lógico admitir, pois, que as disputas em torno da liberdade irremediavelmente cindissem ainda mais escravos e senhores em épocas de expansão econômica, e que entre ambos houvesse, em princípio, certa confluência em fases de crise.

As reflexões de Carneiro da Cunha são razoavelmente antigas. Dentre vários méritos, ensejaram diversas pesquisas sobre as práticas de alforrias e as noções de liberdade manejadas por senhores e escravos, algumas hoje definitivamente incluídas entre os clássicos sobre o tema (37). Outras, em oposição ao modelo insinuado, atestam a existência de correlação positiva entre conjunturas econômicas favoráveis e a frequência de alforrias, como em Sabará e em Mariana na primeira metade do século XVIII, período áureo das manumissões e igualmente auge da economia mineradora (38).

Creio no entanto que a disseminação das pesquisas sobre o tema, ao incorporar outras áreas e períodos, tornará o caso mineiro a típica exceção reiteradora da regra. Veja-se por exemplo a evolução das taxas de manumissão na cidade do Rio de Janeiro entre fins do Setecentos e meados do Oitocentos. Se na década de 1790 , época de relativa estabilidade econômica, a média anual de alforrias registradas no primeiro ofício de notas correspondia a $0,7 \%$ da população escrava, tal porcentagem alcançou apenas $0,3 \%$ por volta de 1840 , mantendo-se nesse patamar em 1850 , em pleno boom cafeeiro.

Há nas alforrias um aspecto pouco explorado por Carneiro da Cunha - a manumissão como conquista escrava. Esclareçamos para evitar mal-entendidos: não se trata de negar o que de concessão senhorial havia em toda e qualquer manumissão, mas sim de realçar os aspectos (práticas, comportamentos sociais, formação de pecúlio, etc.) que tornavam o escravo um ator mais ativo na mudança de sua condição social e jurídica do que comumente se imagina. A Tabela 2 ajuda a explicitar melhor o problema.

Os libertos correspondiam a mais de $50 \%$ da população escrava do Rio de Janeiro em uma época em que metade deles comprava a sua carta de liberdade (1799, fase B), mas caíram para apenas $14 \%$ dos cativos da Corte quando apenas $25 \%$ deles pagavam por sua liberdade (1849, fase A, 
TABELA 2

Flutuações dos preços dos escravos adultos, das alforrias pagas e do total de libertos e escravos nas freguesias urbanas do Rio de Janeiro, 1799-1872

$\begin{array}{lllll}1799 & 1821 & 1838 & 1849 & 1872\end{array}$

$\begin{array}{llllll}\text { Total de escravos } & 14.986 & 36.182 & 37.137 & 78.855 & 37.567\end{array}$

\begin{tabular}{lccccc}
\hline $\begin{array}{l}\text { \% dos libertos frente ao total } \\
\text { de escravos }\end{array}$ & 59 & - & - & 14 & - \\
\hline \% de alforrias pagas & 48 & 49 & 30 & 25 & 25 \\
\hline $\begin{array}{l}\text { Preço médio dos escravos } \\
\text { (em mil-réis) }\end{array}$ & 80 & 158 & 324 & 443 & 1513 \\
\hline
\end{tabular}

Fontes: Preços - Inventários post-mortem (1790-1835, 1860 e 1865), Arquivo Nacional (RJ); Inventários post-mortem (1825-1869), Primeiro Ofício de Notas de Paraiba do Sul (dados coletados por João Fragoso); Inventários postmortem (1820-1869), Arquivo Público Judiciário de Itaguaí (dados coletados por Ricardo Muniz de Ruiz); Alforrias - Livros de Registros de Notas do Primeiro, Segundo e Terceiro Ofícios do Rio de Janeiro - 1789-1871, Arquivo Nacional (RI); e Mary C. Karasch, op. cit., p. 460; Total de escravos e libertos - Mary C. Karasch, op. cit., pp. 109-12; Hermann Burmeister, op. cit., p. 355; e BRASIL, Directoria Geral de Estatística, Resumo Histórico dos Inquéritos Censitários Realizados no Brasil, Rio de Janeiro, Imprensa Nacional, 1922, pp. 193-4.

de absoluto predomínio das alforrias gratuitas) (39). O estupendo aumento do preço do escravo, observado a partir de $1830 \mathrm{e}$, sobretudo, a partir do vislumbre do fim definitivo do tráfico atlântico, em muito contribuiu para o estabelecimento de semelhante transformação. Tal perfil enseja a problematização do modelo de Carneiro da Cunha, apontando para o quanto a alforria comprada podia ter de conquista do escravo. A queda ou o aumento das taxas de manumissões continuariam a refletir as sucessivas conjunturas econômicas mas, tanto quanto redirecionar o cálculo econômico senhorial em relação às alforrias, tais conjunturas, ao atuar sobre os preços dos escravos, tramariam contra ou a favor das possibilidades que os cativos tinham de compra da liberdade - isto é, de obtê-la ou não de acordo com a exclusiva vontade senhorial.

Se semelhante perspectiva for correta, estaremos frente a uma primeira sugestão, de natureza estritamente teórico-metodológica: do ponto de vista analítico, os diferentes tipos de cartas de alforria (compra- das, gratuitas ou obtidas mediante serviços) não devem ser tomados em pé de igualdade com os dados referentes à naturalidade, ao sexo, à idade, às ocupações e às demais variáveis comumente manejadas acerca dos libertandos. Antes, o predomínio de um tipo ou outro de carta expressava o contexto geral em meio ao qual os escravos buscavam a liberdade, sendo por isso signos do entorno em que os padrões etários, sexuais, profissionais e de origem se afirmavam. Sua análise deve, pois, anteceder a desses padrões.

Consoante a esta sugestão, é possível delimitar novas esferas a partir das quais pensar o problema das alforrias. Para começar, no plano da demografia da escravidão, a trajetória descendente dos libertos do Rio de Janeiro entre fins do século XVIII e meados do seguinte sugere que de algum modo as possibilidades de reprodução ampliada da população manumita como um todo, ou de certos setores dela, fossem caudatárias do predomínio do pagamento como forma de obtenção da alforria (40). No plano político, por sua vez, é plausível
39 Cf. Manolo Florentino, "Alfor rias e Etnicidade no Rio de Janeiro Oitocentista (Notas de Pesquisa)", in Topoi, Rio de Janeiro, Programa de Pós-Graduação em História Social da UFR 5, mar. 2002, pp. 9-40.

40 Óbvio, a população forra tem seu crescimento balizado pela frequência de alforrias, dado que todo filho de forro ingênuo é. 
que, muito mais do que quando obtida gratuitamente ou negociada através de serviços futuros, a compra da alforria podia representar a sobreposição da conquista escrava à mera concessão senhorial. Tudo se passa como se o pecúlio acumulado (isto é, o mercado) de certo modo despisse senhores e escravos de suas vestes de mando e obediência, tornando-os simples vendedores e compradores.

Eis a pista que, fazendo interagir demografia e política, eventualmente pode ajudar a explicar por que a compra de uma carta configurava o mecanismo por excelência do crescimento ampliado do número de libertos, ou de certos grupos dentre eles: a freqüência das cartas compradas expressava a habilidade do escravo para autonomamente arregimentar recursos e, por conseguinte, obter ganhos políticos na luta pela liberdade, sobretudo transformando em interlocutores - via mercado - senhores que em princípio não necessariamente compartilhariam da cultura da manumissão.

Em suma, tem razão a historiadora norte-americana Mary Karasch: a liberdade comprada configurava a conquista escrava por excelência (41). Contudo, para além de "iluminar a força do espírito humano na superação de todo o trauma da escravidão”, uma carta comprada era importante pelo que significava e ensejava para o liberto, tanto demográfica e politicamente quanto, em última instância, do ponto de vista da afirmação de sua identidade. A carta comprada é igualmente fundamental para o historiador, posto que, nas condições da escravidão, e de modo muito mais evidente do que nos casos de outros tipos de libertação, ela configurava o resultado último da ação de redes de relações sociais que envolviam os escravos entre si, a família cativa, escravos e senhores, forros, homens livres pobres e instituições como irmandades, lojas maçônicas, caixas de pecúlio,

41 Karasch, op. cit., p. 440.

42 Sobre a noção de redes de relações sociais, cf. Giovann Levi, A Herança Imaterial: Tra ietória de um Exorcista no Piemonte no Século XVII, Rio de Janeiro, Civilização Brasileira 2000, pp. $131-72$ clubes profissionais - enlaçados por meio do mercado (42).

Há também outro tipo de sugestão teórica na compra da liberdade, de dimensão sistêmica, que, ao ultrapassar o cálculo econômico senhorial, introduz referenciais
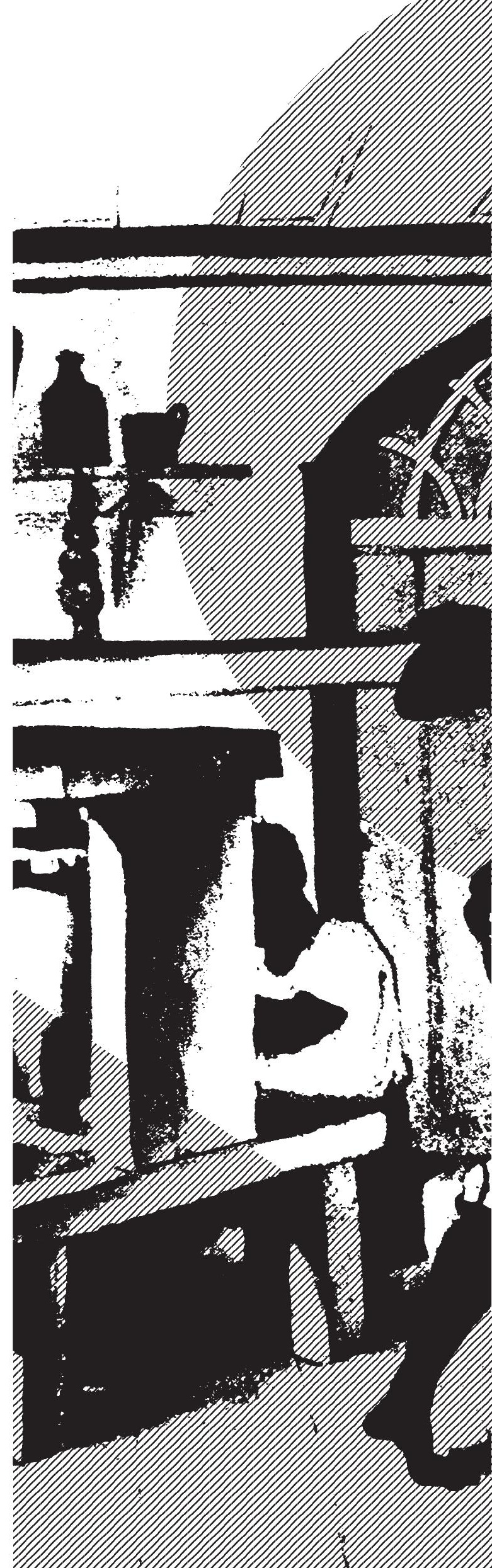
